\title{
Kaitan Pembelajaran Bahasa Indonesia dengan Materi Lingkungan
}

\author{
Ghina Kamilah Siregar 18016157 \\ Universitas Negeri Padang-FBS \\ ghkamilah@gmail.com
}

Lingkungan memiliki peran yang sangat penting bagi kehidupan. Untuk dapat menjaga lingkungan kita membutuhkan pemahaman dan pengetahuan tentang lingkungan. Menurut Ramadhan et.al (2019) Di Indonesia pendidikan lingkungan bukanlah pelajaran wajib di sekolah. Oleh karena itu, pendidikan lingkungan dapat diintegrasikan ke dalam mata pelajaran lain, salah satunya adalah pembelajaran bahasa. Sukma, Ramadhan, dan Indriyani (2020) mengatakan peran penting pendidikan lingkungan adalah mengembangkan individu yang memiliki pengetahuan ilmiah tentang masalah lingkungan dan kepedulian lingkungan yang tinggi dan berpotensi membantu generasi penerus mengelola kehidupan dan membangun masa depan yang sejahtera. Angin, Ramadhan, dan Agustina (2015) mengatakan menggunakan materi lingkungan membuat siswa lebih peka terhadap lingkungannya karena dapat menyajikan hasil pengamatannya.

Ramadhan et.al (2019) mengatakan bahwa guru berperan penting dalam menyampaikan ilmu ini kepada siswa, karena siswa adalah generasi penerus yang bertugas menjaga lingkungan. Pendidikan lingkungan dapat diintegrasikan ke dalam pelajaran pembelajaran bahasa. Pengintegrasian ini dapat kita dilakukan dengan menggunakan tema tentang lingkungan dalam pembelajaran teks. Melalui teks itulah siswa dapat mempelajari bahasa dan mendapatkan pengetahuan lingkungan melalui konten teks yang dibaca.

\footnotetext{
Menurut Sukma (2016) Pembelajaran bahasa merupakan pembelajaran yang menarik. Sukma (2005) mengatakan pembelajaran bahasa menuntut seorang guru agar dapat mengembangkan berbagai teknik dan variasi teknik yang mampu meningkatkan minat siswa untuk belajar. Guru harus tahu apa yang dibutuhkan siswanya bukan hanya sekedar pembelajaran yang tidak bermakna. Ramadan et.al (2019) mengatakan bahwa penggunaan tema lingkungan dalam pembelajaran teks dapat memicu minat siswa belajar bahasa dan secara implisit dapat meningkatkan
} 
pengetahuan siswa tentang lingkungan. Wasillah, Ramadhan, dan Noveria (2016) mengatakan pembelajaran bahasa juga dapat meningkatkan keterampilan berbahasa, memperluas wawasan, dan mendorong siswa untuk memiliki kemampuan bersastra yang komunikatif.

Materi Lingkungan dalam pembelajaran bahasa Indonesia merupakan materi yang sangat penting dan saling berkaitan, sebab dengan memiliki pemahaman yang baik tentang materi lingkungan terutama dalam pembelajaran bahasa Indonesia maka seorang pelajar akan memiliki kepekaan dan kepedulian terhadap lingkungannya, terutama lingkungan kelas dalam pembelajaran bahasa Indonesia. Dalam pembelajaran bahasa Indonesia di sekolah guru harus menjelaskan materi lingkungan dalam pembelajaran bahasa Indonesia di sekolah untuk menjaga kelestarian lingkungan. Sukma (2019) menyatakan bahwa guru hendaknya menyediakan materi yang sesuai dengan kondisi, usia, minat, kebiasaan, maupun lingkungan kehidupan siswa.

Pembelajaran berbasis lingkungan bertujuan untuk membuat siswa berpartisipasi dalam melindungi lingkungan. Tidak memandang lingkungan sebagai sesuatu yang bisa dieksploitasi untuk kepentingan pribadi, tetapi sebagai aset berharga yang layak dilindungi untuk kelangsungan hidup manusia. Oleh karena itu, penting untuk mengembangkan pengetahuan tentang lingkungan, kesadaran lingkungan dan perubahan perilaku terhadap lingkungan. Pendidikan lingkungan dapat membantu siswa memikirkan kembali hubungan antara manusia dan lingkungan, memahami lingkungan, menyadari masalah lingkungan dan mempertimbangkan masalah lingkungan yang berkaitan dengan kehidupan (Ramadhan et.al, 2019).

Berdasarkan permasalahan yang dijabarkan di atas, penulis melakukan penelitian mengenai pentingnya materi lingkungan dalam pembelajaran bahasa Indonesia . Penelitian dilakukan dengan membuat 10 pernyataan dalam bentuk angket google form dengan judul "Kaitan Pembelajaran Bahasa Indonesia dengan Materi Lingkungan". Responden angket terdiri dari 43 orang yaitu 2 orang guru, 39 Mahasiswa dan 2 Pelajar. Kalangan guru berasal dari MTsN 1 Padang Pariaman dan SMP Negeri 6 Panyabungan. Kalangan mahasiswa berasal dari Mahasiswa tersebut berasal dari Universitas Sumatera Utara semester V, Universitas Negeri Padang semester V dan VII, PKN STAN semester III, Universitas Negeri Medan semester V, 
Institut Teknologi Bandung semester $\mathrm{V}$, Universitas Indonesia semester V, Institut Pertanian Bogor semester V, STEI STEBI semester III, Universitas Syiah Kuala Universitas Islam Negeri Sumatera Utara, Universitas Andalas semester V, Poltekpar Medan semester V, Politeknik Pariwisata semester V, Universitas Muhammadiyah Sumatera Utara semester V. Kalangan pelajar berasal dari SMAN 2 Plus Panyabungan kelas XII dan MTsN 2 Madina kelas IX. Responden juga diwajibkan untuk mencantumkan jenis kelamin. Dari jumlah keseluruhan responden yang mengisi angket, ternyata perempuan lebih dominan dibandingkan dengan laki-laki, dengan persentasi perempuan $(79,07 \%)$ dan laki-laki $(20,93 \%)$.

Hasil yang didapat dari penelitian ini adalah sebagai berikut. Pernyataan pertama yaitu materi lingkungan sangat penting dalam pembelajaran bahasa Indonesia mendapatkan hasil setuju 58,14\%, sangat setuju 41,86\%, kurang setuju 0\%, dan tidak setuju 0\%. Pernyataan kedua yaitu materi lingkungan mempermudah siswa dalam memahami pembelajaran bahasa Indonesia mendapatkan hasil setuju 53,49\%, sangat setuju 41,86\%, kurang setuju 4,65\% dan tidak setuju 0\%. Pernyataan ketiga yaitu materi lingkungan layak menjadi salah satu media pembelajaran Bahasa Indonesia mendapatkan hasil setuju 60,5\%, sangat setuju39,5\%, kurang setuju 0\%, dan tidak setuju 0\%. Pernyataan keempat yaitu materi lingkungan dapat mengurangi rasa bosan dan kejenuhan siswa dalam belajar mendapatkan hasil sangat setuju 55,8\%, setuju $37,2 \%$, kurang setuju 4,65\% dan tidak setuju 2,33\%. Pernyataan kelima yaitu materi lingkungan merupakan faktor kondisional yang menciptakan suasana belajar kondusif yang dapat mengembangkan aktifitas dan kreativitas dalam belajar secara optimal, mendapatkan hasil setuju 58,1\%, sangat setuju 39,5\%, kurang setuju 2,33\% dan tidak setuju 0\%. Pernyataan keenam yaitu salah satu faktor yang mempengarhui hasil belajar siswa merupakan lingkungan yang mendapatkan hasil sangat setuju 48,8\%, setuju $48,8 \%$, kurang setuju $2,33 \%$ dan tidak setuju 0\%. Pernyataan ketujuh yaitu pemanfaatan lingkungan merupakan salah satu media pembelajaran yang baik untuk diterapkan dalam proses belajar yang mendapatkan hasil sangat setuju 55,8\%, setuju 44,2\%, kurang setuju 0\%, dan tidak setuju 0\%. Pernyataan kedelapan yaitu materi lingkungan dapat dikaitkan dengan teks eksplanasi yang berisi penjelasan atas sbuah kejadian atau fenomena yang berkaitan dengan alam, sosial, ilmuah, dan budaya, mendapatkan hasil sangat setuju 51,2\%, setuju 46,5\%, kurang setuju 2,33\%, dan $0 \%$ 
tidak setuju. Pernyataan kesembilan yaitu pendekatan lingkungan merupakan pendekatan pembelajaran yang berusaha untuk meningkatkan keterlibatan siswa melalui pendayagunaan lingkungan sebagai sumber belahar yang mendapatkan hasil setuju $65,1 \%$, sangat setuju 32,6\%, tidak setuju 2,33\% dan $0 \%$ kurang setuju. Pernyataan kesepuluh yaitu pembelajaran bahasa indonesia dan materi lingkungan berkaitan erat dan tidak dapat dipisahkan yang mendapatkan hasil setuju76,7\%, sangat setuju 20,9\% , kurang setuju 2,33\%, dan tidak setuju $0 \%$.

Berdasarkan hasil kajian dan penelitian yang dilakukan penulis, dapat disimpulkan bahwasannya materi lingkungan memiliki peran penting dan juga keterkaitan dengan pembelajaran bahasa Indonesia. Pendidikan wawasan lingkungan dapat dintegrasikan kedalam subyek mata pelajaran dan mata pelajaran bahasa Indonesia untuk memberikan pengetahuan dan ketrampilan komprehensif dalam menjaga lingkungan. Materi lingkungan juga dapat mempermudah tenaga pendidik dalam mengajarkan materi pembelajaran terutama dalam pembelajaran bahasa Indonesia. Berdasarkan penelitian yang dilakukan penulis suara yang didapatkan dapat menunjukkan materi lingkungan memiliki kaitan erat dengan pembelajaran bahasa Indonesia. 


\section{Lampiran Rangkuman Hasil Angket}

"Kaitan Pembelajaran Bahasa Indonesia dengan Materi Lingkungan"

\begin{tabular}{|c|c|c|c|c|}
\hline Pernyataan & $\begin{array}{l}\text { Sangat } \\
\text { setuju }\end{array}$ & Setuju & $\begin{array}{c}\text { Kurang } \\
\text { setuju }\end{array}$ & $\begin{array}{l}\text { Tidak } \\
\text { setuju }\end{array}$ \\
\hline $\begin{array}{l}\text { Materi Lingkungan sangat penting } \\
\text { dalam pembelajaran Bahasa } \\
\text { Indonesia }\end{array}$ & $41 \%$ & $58 \%$ & - & - \\
\hline $\begin{array}{l}\text { Materi Lingkungan } \\
\text { mempermudah siswa dalam } \\
\text { memahami pembelajaran Bahasa } \\
\text { Indonesia }\end{array}$ & $53,5 \%$ & $41,9 \%$ & $4,65 \%$ & - \\
\hline $\begin{array}{l}\text { Materi Lingkungan layak menjadi } \\
\text { salah satu media pembelajaran } \\
\text { Bahasa Indonesia }\end{array}$ & $39,5 \%$ & $60,5 \%$ & - & - \\
\hline $\begin{array}{l}\text { Materi Lingkungan dapat } \\
\text { mengurangi rasa bosan dan } \\
\text { kejenuhan siswa dalam belajar. }\end{array}$ & $55,8 \%$ & $37,2 \%$ & $4,65 \%$ & $2,33 \%$ \\
\hline $\begin{array}{l}\text { Materi lingkungan merupakan } \\
\text { faktor kondisional yang } \\
\text { menciptakan suasana belajar } \\
\text { kondusif yang dapat } \\
\text { mengembangkan aktivitas dan } \\
\text { kreativitas belajar secara optimal }\end{array}$ & $39,5 \%$ & $58,1 \%$ & $2,33 \%$ & - \\
\hline $\begin{array}{l}\text { Salah satu faktor yang } \\
\text { memengaruhi hasil belajar siswa } \\
\text { merupakan lingkungan }\end{array}$ & $48,8 \%$ & $48,8 \%$ & $2,33 \%$ & - \\
\hline $\begin{array}{l}\text { Pemanfaatan lingkungan } \\
\text { merupakan salah satu media } \\
\text { pembelajaran yang baik untuk } \\
\text { diterapkan dalam proses belajar }\end{array}$ & $55,8 \%$ & $44,2 \%$ & - & - \\
\hline $\begin{array}{l}\text { Materi Lingkungan dapat } \\
\text { dikaitkan dengan teks eksplanasi } \\
\text { yang berisi penjelasan atas sebuah } \\
\text { kejadian atau fenomena yang } \\
\text { berkaitan dengan alam, sosial, } \\
\text { ilmiah, dan budaya. }\end{array}$ & $51,2 \%$ & $46,5 \%$ & $2,33 \%$ & - \\
\hline $\begin{array}{l}\text { Pendekatan lingkungan merupakan } \\
\text { pendekatan pembelajaran yang } \\
\text { berusaha untuk meningkatkan } \\
\text { keterlibatan siswa melalui } \\
\text { pendayagunaan lingkungan } \\
\text { sebagai sumber belajar }\end{array}$ & $32,6 \%$ & $65,1 \%$ & - & $2,33 \%$ \\
\hline $\begin{array}{l}\text { Pembelajaran bahasa Indonesia } \\
\text { dan materi lingkungan berkaitan } \\
\text { erat dan tidak dapat dipisahkan }\end{array}$ & $20.9 \%$ & $76,7 \%$ & $2,33 \%$ & - \\
\hline
\end{tabular}




\section{Daftar Pustaka}

Ramadhan, S., Sukma, E., \&Indriyani, V. (2019). Environmental education and disaster mitigation through language learning

Ramadhan, S., Sukma, E., \& Indriyani, V. (2019). Environmental education and disaster mitigation through language learning. IOP Conference Series: Earth and Environmental Science, 314, pp. 1-9.

Ramadhan, S., Zaim M., Atmazaki., \& Indriyani, V.(2019) Literasi Baca Tulis dan Inovasi Kurikulum Bahasa: Jurnal Kembara. Vol 5 No 1.

Ramadhan, S., Sukma, E., \& Indriyani, V. (2019). Persepsi Guru Terhadap Penggunaan Bahan Ajar Bahasa Indonesia Dengan Perangkat Seluler dan Aplikasi Edmodo: Seminar Internasional Riksa Bahasa XIII.

Wasilah, Tri, R., Syahrul, Noveria, Ena. (2016). Pengaruh Model Pembelajaran Kooperatif Tipe Think Pair Share terhadap Keterampilan Menulis Naskah Drama Satu Babak Siswa Kelas VIII SMP Negeri 30 Padang. Jurnal Pendidikan Bahasa dan Sastra Indonesia. 5(1); 810.

Angin, Toras Barita Bayo, Ramadhan, Syahrul, Agustina. (2015). Berbasis Pendekatan Kontekstual Pada Menulis Iklan Di Kelas VIII SMP 2 Padangsidimpuan Sumatera Utara. Jurnal Bahasa, Sastra, dan Pembelajaran. 3(1); 27-31.

Sukma, E. (2005). Penerapan Pendekatan Komunikatif dalam Pembelajaran Struktur Bahasa Indonesia di Sekolah Dasar. Diksi. Vol 2 No.1

Sukma, E. (2019). Problem in oral language teaching in primary school. Seventh international conference on languages and arts(ICLA 2018). Atlantis press.

Sukma, E, Ramadhan, S, Indriyani, V. 2020. Integration Of Environmental Education In Elementary Schools. Journal of Physics: Conference Series. 1481(1): 1-2.

Sukma dan Bacthiar (2016). Kompetensi kognitif pembelajaran apresiasi sastra di sekolah dasar. Jurnal Gramatika. 2(1). 